www.mdpi.com/journal/applsci

Article

\title{
CERN-MEDICIS (Medical Isotopes Collected from ISOLDE): A New Facility
}

Ricardo Manuel dos Santos Augusto ${ }^{1}$, Leo Buehler ${ }^{2}$, Zoe Lawson ${ }^{1}$, Stefano Marzari ${ }^{1}$, Monika Stachura ${ }^{1}$, Thierry Stora ${ }^{1, *}$ and CERN-MEDICIS collaboration ${ }^{1}$

1 CERN, 23 Geneva, 1211-Geneva, Switzerland; E-Mails: r.s.augusto@cern.ch (R.M.S.A.); zoe.lawson@cern.ch (Z.L.); stefano.marzari@cern.ch (S.M.); monika.stachura@cern.ch (M.S.)

2 Hôpitaux Universitaires de Genève (HUG), Rue Gabrielle-Perret-Gentil 4, 1205-Geneva, Switzerland; E-Mail: leo.buhler@hcuge.ch

* Author to whom correspondence should be addressed; E-Mail: thierry.stora@cern.ch; Tel.: +41-22-767-6878; Fax: +41-22-767-8790.

Received: 10 November 2014; in revised form: 27 January 2014 / Accepted: 25 February 2014 / Published: 16 May 2014

\begin{abstract}
About $50 \%$ of the $1.4 \mathrm{GeV}$ CERN (European Organization for Nuclear Research, www.cern.ch) protons are sent onto targets to produce radioactive beams by online mass separation at the Isotope Separator Online Device (ISOLDE) facility, for a wide range of studies in fundamental and applied physics. CERN-MEDICIS is a spin-off dedicated to R\&D in life sciences and medical applications. It is located in an extension of the Class A building presently under construction. It will comprise laboratories to receive the irradiated targets from a new station located at the dump position behind the ISOLDE production targets. An increasing range of innovative isotopes will thus progressively become accessible from the start-up of the facility in 2015 onward; for fundamental studies in cancer research, for new imaging and therapy protocols in cell and animal models and for pre-clinical trials, possibly extended to specific early phase clinical studies up to Phase I trials. Five hundred megabecquerel isotope batches purified by electromagnetic mass separation combined with chemical methods will be collected on a weekly basis. A possible future upgrade with gigabecquerel pharmaceutical-grade i.e., current good manufacturing practices (cGMP) batch production capabilities is finally presented.
\end{abstract}


Keywords: CERN-MEDICIS; ISOLDE; CERN; radioisotope; radiolanthanides; bioconjugates; targeted radiotherapy; targeted alpha therapy (TAT); cancer; PET imaging; theranostics

\section{Introduction}

The application of radioisotopes in medicine was proposed shortly after the discovery of radioactivity about a century ago by Prof. Pierre Curie and MD. Henri Danlos. ${ }^{223} \mathrm{Ra}$ and ${ }^{224} \mathrm{Ra}$ alpha-emitters were applied to skin lesions in the treatment of Lupus disease. Over the years, new isotopes and isomers from the known chemical elements have been produced, isolated and identified and the periodic table extended to new artificial and radioactive elements - the transactinide and super-heavy elements. Together with the important progresses witnessed in inorganic chemistry, molecular biology, accelerators, diagnostics, imaging and nuclear technology, ever more sophisticated, and efficient, radiopharmaceuticals and protocols have been conceived, tested and successfully used by the medical community. This goes along evolving rules in the pharmacopoeia and the precaution required for a safe handling of the radioisotopes for the general public, medical personnel and the environment. While a few radiopharmaceuticals have by now widely found their place for imaging and treatments, such as the 2-deoxy-2-(18F)fluoro-D-glucose (18F-FDG) metabolism PET tracer or the various ${ }^{99 \mathrm{~m}} \mathrm{Tc}$-labeled imaging agents, and cover most of the radiolabels used in the present medical protocols, emerging isotopes and compounds for imaging and treatment, such as ${ }^{64,67} \mathrm{Cu}-\mathrm{ASTM}$ and ${ }^{177} \mathrm{Lu}$-rituximab, are expected to gain importance. The production routes for these five isotopes already cover the principal accessible methods, that is using small medical cyclotrons, nuclear reactors and larger accelerators, such as the tens of kilowatt, hundreds of megaelectron volts-range electron or proton linacs. Most of these methods exploit natural or enriched targets combined with an appropriate driver particle and energy to induce nuclear reactions with maximal production cross-sections for either the desired or the parent nuclei. The eventual subsequent purification step is done by radiochemical methods. The combination of such a long-lived radioisotope source and separation combined into automated shielded modules are named isotope generators, which can be used directly onsite in hospitals in nuclear medicine departments.

Pure isotope sources have also been historically made by the so-called Isotope Separation Online (ISOL) technique, which produces isotope beams by irradiation of thick natural targets, the generation of a low-energy secondary ion beam and subsequent electromagnetic separation. These isotopes can be used as sources of implanted radiotracers in fundamental and applied sciences, such as in solid state physics and life sciences, as local probes for magnetic, electrical and diffusion properties in crystalline lattices, or for the conformation properties of proteins. The ISOL technique has constantly been developed at ISOLDE at CERN for over 40 years, a facility located today at the external $1.4 \mathrm{GeV}$ proton beam of the Proton Synchrotron Booster (PSB). It offers more than 1000 different isotope beams of 70 chemical elements; these two figures being in constant progression. 


\section{CERN-MEDICIS Facility}

The ISOLDE facility has been located at the external beam of the CERN's PSB since 1991. It operates two electromagnetic mass spectrometers in a sequential mode, one delivering a beam for physics experiments, while the other primes. A regular operating year lasts for 30 weeks, seeing about $50 \%$ of CERN's $1.4 \mathrm{GeV}$ protons. ISOLDE started operating the post-accelerating High Intensity and Energy (HIE)-ISOLDE Linac about 10 years ago to extend the physics program towards nuclear structure investigations by Coulomb excitation and transfer reaction studies. On the target station side, a new Class A work sector for handling open radiological sources was built in 2004. Presently, a major upgrade of the facility, which will upgrade the post-accelerating Linac with superconducting accelerating cavities, is ongoing; in parallel, a design study for the beam quality improvement and for an upgrade in proton beam intensity and energy is also being performed. The new facility for the start-up in 2014 following the CERN-wide Long Shut-Down 1 can be seen in Figure 1.

Figure 1. Construction of the CERN-MEDICIS (Medical Isotopes Collected from ISOLDE) extension of the "Class A" Building 179 in blue will be finished in 2014. Services and laboratory equipment will then be installed, while the rest of the ISOLDE facility will resume operations in the following years. The dashed lines correspond to the entrance zone to the facility, before it is fully connected to the existing building.

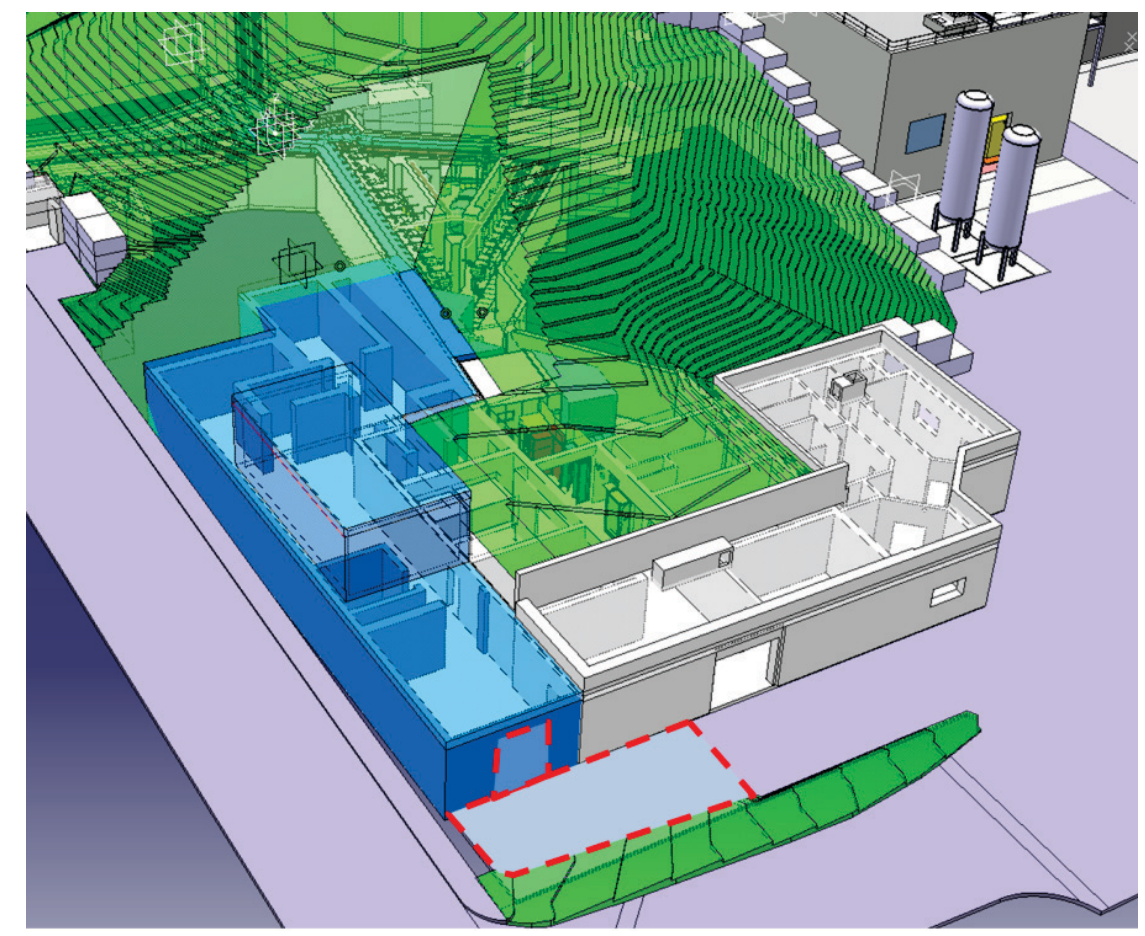

The long shutdown period (January 2013 to July 2014) provides an opportune time window to upgrade the existing ISOLDE facility with some HIE-ISOLDE infrastructure and the extension of Building 179, which will host CERN-MEDICIS radiological Class A laboratory for biomedical research, as well as ISOLDE's target storage area.

These new structures will also host mechanical and chemical laboratory equipment and the fundamental elements for CERN-MEDICIS's operation. This includes: 
A rail conveyor system (RCS) based on an industrial system, modified to bring the CERN-MEDICIS sample from the ISOLDE irradiation area to a shielded decay area. Once there, a robot acquired from the KUKA company (Augsburg, Germany) completes the target transport cycle.

A heavy concrete hot-cell, for target preparation, and a bunker equipped with a mass separator, provided by the Katholieke Universiteit (KU) Leuven, for radioactive isotope mass separation.

CERN-MEDICIS will produce radioactive isotopes by recovering the proton beam before it reaches the beam dump, using different types of targets behind the ISOLDE targets; CERN-MEDICIS will form a symbiotic relationship with ISOLDE, taking advantage of the latter's unique ability, and experience to provide exotic carrier-free isotopes, while remaining transparent to its operation. In addition, the project will benefit from CERN's nanostructured target patent to efficiently extract the isotopes with an offline mass separator before the chemical purification step [1].

Since advanced medical applications rely on the use of specific isotopes, CERN-MEDICIS's target material is crucial for achieving significant production. During its initial stage in 2016, only low atomic number $\mathrm{Z}$ materials, such as titanium foils and $\mathrm{Y}_{2} \mathrm{O}_{3}$ ceramics, will be used; from these, we will produce batches of several hundreds of megabecquerels of ${ }^{44,47} \mathrm{Sc}$ and ${ }^{61,64} \mathrm{Cu}$ (Tables 1 and 2). In the second stage, tentatively in 2017, we will use targets from the nuclei of higher atomic numbers, such as tantalum foils, reaching some of the most interesting terbium and lanthanide isotopes; in a final phase in 2018, we foresee the use of uranium carbide to reach an even wider range of isotopes and most of the other alpha-emitters. The preliminary planning for the construction of the facility and its start-up following a staged scheme is shown in Table 3.

Table 1. Different target densities (grams per cubic centimeter).

\begin{tabular}{ccc}
\hline Target material & ISOLDE & CERN-MEDICIS \\
\hline $\mathrm{Ti}$ & 0.80 & 2.5 \\
$\mathrm{Y}_{2} \mathrm{O}_{3}$ & 1.7 & 2.3 \\
$\mathrm{Ta}$ & 2.0 & 6.0 \\
$\mathrm{UC}_{2}$ & 3.5 & 7.0 \\
\hline
\end{tabular}

As ISOLDE receives about $50 \%$ of all CERN protons, and from these, about $85 \%$ traverse the ISOLDE target without any interaction, using a CERN-MEDICIS target not only adds value to this lost beam, but also takes advantage of the fact that a large part of its characteristics remain intact. The optimal distance between the CERN-MEDICIS sample and ISOLDE target was defined as $400 \mathrm{~mm}$.

In the upgraded beam version $(2.0 \mathrm{GeV}, 6 \mu \mathrm{A})$ each CERN-MEDICIS sample is expected to receive about $5 \times 10^{18}$ protons in a few days, increasing production rates by at least a factor of three compared to the facility at start-up.

After irradiation, the CERN-MEDICIS sample is transported back into the extension area by the rail conveyor system in $10 \mathrm{~min}$. The target is placed in a shielded decay and monitoring area, for a suitable time, depending on the type of target and isotope to be extracted. It is then either directly coupled to the CERN-MEDICIS mass separator in the bunker or first transferred in a dedicated hot cell for a fast preparation before starting the batch extraction. 
Table 2. Isotope production at CERN MEDICIS.

\begin{tabular}{|c|c|c|c|c|c|c|c|c|c|c|c|c|}
\hline \multirow{3}{*}{$\begin{array}{c}\text { Medical } \\
\text { Application }\end{array}$} & \multirow{3}{*}{$\begin{array}{l}\text { Isotope } \\
\text { half-life }\end{array}$} & \multirow{3}{*}{$\begin{array}{c}\text { Parent } \\
\text { isotope } \\
\text { beam }\end{array}$} & \multirow{3}{*}{$\begin{array}{l}\text { Target } \\
\text { ion } \\
\text { source }\end{array}$} & \multirow{2}{*}{\multicolumn{2}{|c|}{$\frac{\text { ISOLDE }^{\dagger}}{\text { In-target }}$}} & \multirow{3}{*}{$\begin{array}{c}\text { RIB } \\
\varepsilon_{\mathrm{ext}} * *(\%)\end{array}$} & \multicolumn{2}{|c|}{ CERN-MEDICIS $^{\dagger}$} & \multicolumn{3}{|c|}{ CERN-MEDICIS $2 \mathrm{GeV} 6 \mu \mathrm{A}$} & \multirow{3}{*}{ Comments } \\
\hline & & & & & & & \multirow{2}{*}{$\begin{array}{c}\text { In-target } \\
\text { Activity }_{\mathrm{EOB}} \\
(\mathrm{Bq})\end{array}$} & \multirow{2}{*}{$\begin{array}{c}\text { Extracted } \\
\text { Activity }_{\mathrm{EOB}} \\
(\mathrm{Bq})\end{array}$} & \multirow{2}{*}{$\begin{array}{c}\text { Possible } \\
\text { gain } \\
\varepsilon_{\text {ext }}(\%) \\
\end{array}$} & \multirow{2}{*}{$\begin{array}{c}\text { In-target } \\
\text { Activity } \\
\text { (B) } \\
\text { (Bq) } \\
\end{array}$} & \multirow{2}{*}{$\begin{array}{c}\text { Extracted } \\
\text { Activity }_{\mathrm{EOB}} \\
(\mathrm{Bq})\end{array}$} & \\
\hline & & & & $\begin{array}{c}\text { Production } \\
\text { rate }(\mathrm{pps})\end{array}$ & $\begin{array}{c}\text { Activity }_{\mathrm{EOB}} \\
(\mathrm{Bq})\end{array}$ & & & & & & & \\
\hline $\begin{array}{c}\alpha, \beta \text { therapy/ } \\
\text { SPECT/ }\end{array}$ & $\begin{array}{c}{ }^{213} \mathrm{Bi} \\
45.6 \mathrm{~m}\end{array}$ & ${ }^{225} \mathrm{Ac}$ & $\mathrm{UC}_{\mathrm{X}}-\mathrm{Re}$ & $1.5 \mathrm{E} 9 *$ & $7.2 \mathrm{E} 8$ & ${ }^{221} \operatorname{Fr} 10$ & $2.8 \mathrm{E} 8$ & $2.8 \mathrm{E} 7$ & 50 & $8.4 \mathrm{E} 8$ & $4.2 \mathrm{E} 8$ & $\begin{array}{l}\text { Only mass } \\
\text { separation }\end{array}$ \\
\hline$\alpha, \beta$ therapy & $\begin{array}{l}{ }^{212} \mathrm{Bi} \\
60.6 \mathrm{~m}\end{array}$ & ${ }^{224} \mathrm{Ac}$ & $\mathrm{UC}_{\mathrm{X}}-\mathrm{Re}$ & $1.5 \mathrm{E} 9 *$ & $1.4 \mathrm{E} 9$ & ${ }^{220} \operatorname{Fr} 10$ & $1.7 \mathrm{E} 9$ & $1.7 \mathrm{E} 8$ & 50 & $5.1 \mathrm{E} 9$ & $2.5 \mathrm{E} 9$ & $\begin{array}{l}\text { Only mass } \\
\text { separation }\end{array}$ \\
\hline$\beta$ therapy & $\begin{array}{l}{ }^{177} \mathrm{Lu} \\
6.7 d\end{array}$ & $\begin{array}{c}{ }^{177} \mathrm{Lu} \\
\text { RILIS/VD }\end{array}$ & $\begin{array}{c}\text { Ta-Rel } \\
R e-V D 5\end{array}$ & $3.3 E 9$ & $7.4 E 8$ & ${ }^{177} \mathrm{Lu} 1$ & $6.4 E 8$ & $6.4 E 6$ & 20 & $8.3 E 8$ & $1.7 \mathrm{E} 8$ & $\begin{array}{c}\text { Chemical } \\
\text { purification }\end{array}$ \\
\hline Auger therapy & $\begin{array}{l}{ }^{166} \mathrm{Yb} \\
56.7 \mathrm{~h} \\
\end{array}$ & ${ }^{166} \mathrm{Yb}$ & Ta-Re & $1.4 \mathrm{E} 10$ & 5.4 E10 & ${ }^{166} \mathrm{Yb} 5$ & 4.1 E10 & $2.1 \mathrm{E} 9$ & 20 & 5.4 E10 & 1.1 E10 & $\begin{array}{l}\text { Chemical } \\
\text { purification }\end{array}$ \\
\hline$\beta$ therapy & $\begin{array}{r}{ }^{166} \mathrm{Ho} \\
25.8 \mathrm{~h}\end{array}$ & ${ }^{166} \mathrm{Ho}$ & $T a-R e$ & $1.4 E 7$ & $1.2 \mathrm{E7}$ & ${ }^{166} \mathrm{Ho} 5$ & $9.6 E 6$ & $4.8 E 5$ & 20 & $2.9 E 7$ & $6.0 E 6$ & $\begin{array}{c}\text { Chemical } \\
\text { purification }\end{array}$ \\
\hline $\begin{array}{c}\beta \text { therapy } \\
\text { /Auger therapy }\end{array}$ & $\begin{array}{l}{ }^{161} \mathrm{~Tb} \\
6.9 d \\
\end{array}$ & ${ }^{161} \mathrm{~Tb}$ & $U C_{X}-R e$ & $2.1 E 7$ & 2.7 E7 & ${ }^{161} \mathrm{~Tb} 5$ & $1.9 \mathrm{E7}$ & $9.5 E 5$ & 20 & $2.7 E 7$ & $5.4 E 6$ & $\begin{array}{c}\text { Chemical } \\
\text { purification }\end{array}$ \\
\hline PET & $\begin{array}{l}{ }^{156} \mathrm{~Tb} \\
5.35 d\end{array}$ & ${ }^{156} \mathrm{~Tb}$ & $T a-R e$ & $2.5 E 8$ & $8.9 E 7$ & ${ }^{156} \mathrm{~Tb} 1$ & $5.5 E 7$ & $5.5 E 5$ & 20 & $6.3 E 7$ & $1.3 E 7$ & $\begin{array}{c}\text { Chemical } \\
\text { purification }\end{array}$ \\
\hline $\begin{array}{c}\text { SPECT/ } \\
\text { CT diagnosis }\end{array}$ & $\begin{array}{l}{ }^{155} \mathrm{~Tb} \\
5.33 \mathrm{~d}\end{array}$ & $\begin{array}{l}{ }^{155} \mathrm{Dy} / \\
\mathrm{Tb}\end{array}$ & Ta-Re & $\begin{array}{l}3.2 \mathrm{E} 9 / \\
7.4 \mathrm{E} 8\end{array}$ & 7.9 E9 & ${ }^{155}$ Dy 1 & $5.3 \mathrm{E} 9$ & $5.3 \mathrm{E} 7$ & 20 & $3.4 \mathrm{E} 9$ & $6.8 \mathrm{E} 8$ & RILIS Dy \\
\hline$\beta$ therapy & $\begin{array}{r}{ }^{153} \mathrm{Sm} \\
46.8 \mathrm{~h} \\
\end{array}$ & ${ }^{153} \mathrm{Sm}$ & $\mathrm{UC}_{\mathrm{X}}-\mathrm{Re}$ & $1.5 \mathrm{E} 8$ & $2.2 \mathrm{E} 9$ & ${ }^{153} \mathrm{Sm} 5$ & $2.8 \mathrm{E} 9$ & $1.4 \mathrm{E} 8$ & 20 & $5.2 \mathrm{E} 9$ & $1.0 \mathrm{E} 9$ & $\begin{array}{l}\text { Chemical } \\
\text { purification }\end{array}$ \\
\hline $\mathrm{PET} / \mathrm{CT}$ & $\begin{array}{r}{ }^{152} \mathrm{~Tb} \\
17.5 \mathrm{~h} \\
\end{array}$ & $\begin{array}{c}{ }^{152} \mathrm{Dy} / \\
\mathrm{Tb}\end{array}$ & Ta-Re & $\begin{array}{l}1.3 \mathrm{E} 10 / \\
3.3 \mathrm{E} 9\end{array}$ & $5.6 \mathrm{E} 10$ & ${ }^{152}$ Dy 1 & $3.7 \mathrm{E} 10$ & $3.7 \mathrm{E} 8$ & 20 & $1.1 \mathrm{E} 11$ & 2.2 E10 & RILIS Dy \\
\hline$\alpha$ therapy & $\begin{array}{l}{ }^{149} \mathrm{~Tb} \\
4.1 \mathrm{~h} \\
\end{array}$ & ${ }^{149} \mathrm{~Tb}$ & Ta-Re & $1.1 \mathrm{E} 10$ & 6.0 E10 & ${ }^{149} \mathrm{~Tb} 1$ & $3.8 \mathrm{E} 10$ & $3.8 \mathrm{E} 8$ & 20 & $1.2 \mathrm{E} 11$ & 2.4 E10 & $\begin{array}{c}\text { Chemical } \\
\text { purification }\end{array}$ \\
\hline $\begin{array}{l}{ }^{140} \mathrm{Pr}-\mathrm{PET} / \\
\text { Auger therapy }\end{array}$ & $\begin{array}{l}{ }^{140} \mathrm{Nd} \\
3.4 \mathrm{~d}\end{array}$ & ${ }^{140} \mathrm{Nd}$ & Ta-Re & $1.8 \mathrm{E} 9$ & $2.0 \mathrm{E} 10$ & ${ }^{140} \mathrm{Nd} 5$ & $1.2 \mathrm{E} 10$ & $6.0 \mathrm{E} 8$ & 20 & $2.0 \mathrm{E} 10$ & $4.0 \mathrm{E} 9$ & $\begin{array}{l}\text { Chemical } \\
\text { purification }\end{array}$ \\
\hline
\end{tabular}


Table 2. Cont

\begin{tabular}{|c|c|c|c|c|c|c|c|c|c|c|c|c|}
\hline \multirow{3}{*}{$\begin{array}{c}\text { Medical } \\
\text { Application }\end{array}$} & \multirow{3}{*}{$\begin{array}{l}\text { Isotope } \\
\text { half-life }\end{array}$} & \multirow{3}{*}{$\begin{array}{l}\text { Parent } \\
\text { isotope } \\
\text { beam }\end{array}$} & \multirow{3}{*}{$\begin{array}{l}\text { Target ion } \\
\text { source }\end{array}$} & \multirow{2}{*}{\multicolumn{2}{|c|}{$\begin{array}{c}\text { ISOLDE }^{\dagger} \\
\text { In-target }\end{array}$}} & \multirow{3}{*}{$\begin{array}{c}\mathrm{RIB} \varepsilon_{\mathrm{ext}} * * \\
(\%)\end{array}$} & \multicolumn{2}{|c|}{ CERN-MEDICIS $^{\dagger}$} & \multicolumn{3}{|c|}{ CERN-MEDICIS 2GeV $6 \mu \mathrm{A}$} & \multirow{3}{*}{ Comments } \\
\hline & & & & & & & \multirow{2}{*}{$\begin{array}{c}\text { In-target } \\
\text { Activity }_{\mathrm{EOB}} \\
(\mathrm{Bq}) \\
\end{array}$} & \multirow{2}{*}{$\begin{array}{c}\text { Extracted } \\
\text { Activity\# } \#_{\mathrm{EOB}} \\
(\mathrm{Bq}) \\
\end{array}$} & \multirow{2}{*}{$\begin{array}{c}\text { Possible } \\
\text { gain } \\
\varepsilon_{\text {ext }}(\%) \\
\end{array}$} & \multirow{2}{*}{$\begin{array}{c}\text { In-target } \\
\text { Activity } \\
\text { EOB } \\
(\mathrm{Bq}) \\
\end{array}$} & \multirow{2}{*}{$\begin{array}{c}\text { Extracted } \\
\text { Activity\# } \\
\text { (BOB } \\
(\mathrm{Bq})\end{array}$} & \\
\hline & & & & $\begin{array}{c}\text { Production } \\
\text { rate }(\mathrm{pps})\end{array}$ & $\begin{array}{c}\text { Activity }_{\mathrm{EOB}} \\
(\mathrm{Bq})\end{array}$ & & & & & & & \\
\hline$\beta$ therapy & $\begin{array}{c}{ }^{89} \mathrm{Sr} \\
50.5 \mathrm{~d} \\
\end{array}$ & ${ }^{89} \mathrm{Sr}$ & $\mathrm{UC}_{\mathrm{X}}-\mathrm{Re}$ & $1.2 \mathrm{E} 10$ & $2.3 \mathrm{E} 9$ & ${ }^{89} \mathrm{Sr} 5$ & $2.0 \mathrm{E} 9$ & $1.0 \mathrm{E} 8$ & 20 & $2.7 \mathrm{E} 9$ & $5.4 \mathrm{E} 8$ & $\begin{array}{l}\text { Only mass } \\
\text { separation }\end{array}$ \\
\hline PET & $\begin{array}{l}{ }^{82} \mathrm{Sr} \\
25.5 \mathrm{~d} \\
\end{array}$ & ${ }^{82} \mathrm{Sr}$ & $\mathrm{UC}_{\mathrm{X}}-\mathrm{Re}$ & $3.6 \mathrm{E} 10$ & 4.6 E9 & ${ }^{82} \mathrm{Sr} 5$ & 1.7 E9 & $8.5 \mathrm{E} 7$ & 20 & $2.0 \mathrm{E} 9$ & $4.0 \mathrm{E} 8$ & $\begin{array}{l}\text { Only mass } \\
\text { separation }\end{array}$ \\
\hline$\beta$ therapy & $\begin{array}{l}{ }^{77} \mathrm{As} \\
38.8 \mathrm{~h}\end{array}$ & ${ }^{77} \mathrm{As}$ & $\mathrm{UC}_{\mathrm{X}}-\mathrm{VD} 5$ & 5.7 E9 & $1.1 \mathrm{E} 10$ & ${ }^{77}$ As 5 & $5.8 \mathrm{E} 9$ & $2.9 \mathrm{E} 8$ & 20 & 9.4 E9 & $1.4 \mathrm{E} 9$ & $\begin{array}{l}\text { Chemical } \\
\text { purification }\end{array}$ \\
\hline PET & $\begin{array}{l}{ }^{74} \mathrm{As} \\
17.8 \mathrm{~d}\end{array}$ & ${ }^{74} \mathrm{As}$ & $\mathrm{Y}_{2} \mathrm{O}_{3}-\mathrm{VD} 5$ & $6.5 \mathrm{E} 9$ & $1.2 \mathrm{E} 9$ & ${ }^{74}$ As 5 & $3.8 \mathrm{E} 8$ & $1.9 \mathrm{E} 7$ & 20 & $4.5 \mathrm{E} 8$ & $9.0 \mathrm{E} 7$ & $\begin{array}{l}\text { Chemical } \\
\text { purification }\end{array}$ \\
\hline PET & $\begin{array}{l}{ }^{72} \mathrm{As} \\
26.0 \mathrm{~d}\end{array}$ & ${ }^{72} \mathrm{As}$ & $\mathrm{Y}_{2} \mathrm{O}_{3}-\mathrm{VD} 5$ & $1.6 \mathrm{E} 10$ & $2.8 \mathrm{E} 10$ & ${ }^{72}$ As 5 & $9.1 \mathrm{E} 9$ & 4.6 E8 & 20 & $1.5 \mathrm{E} 10$ & $3.0 \mathrm{E} 9$ & $\begin{array}{l}\text { Chemical } \\
\text { purification }\end{array}$ \\
\hline PET & $\begin{array}{l}{ }^{71} \mathrm{As} \\
65.3 \mathrm{~h}\end{array}$ & ${ }^{71}$ As & $\mathrm{Y}_{2} \mathrm{O}_{3}$-VD5 & $1.8 \mathrm{E} 10$ & $1.8 \mathrm{E} 10$ & ${ }^{71}$ As 5 & 5.9 E9 & $3.0 \mathrm{E} 8$ & 20 & 8.0 E9 & $1.6 \mathrm{E} 9$ & $\begin{array}{l}\text { Chemical } \\
\text { purification }\end{array}$ \\
\hline$\beta$ therapy & $\begin{array}{l}{ }^{67} \mathrm{Cu} \\
61.9 \mathrm{~h} \\
\end{array}$ & ${ }^{67} \mathrm{Cu}$ & $\mathrm{UC}_{\mathrm{X}}-\mathrm{Re}$ & $2.7 \mathrm{E} 9$ & $3.4 \mathrm{E} 9$ & ${ }^{67} \mathrm{Cu} 7$ & $1.5 \mathrm{E} 9$ & $1.1 \mathrm{E} 8$ & 20 & $2.7 \mathrm{E} 9$ & $5.4 \mathrm{E} 8$ & $\begin{array}{l}\text { Chemical } \\
\text { purification }\end{array}$ \\
\hline $\begin{array}{c}\text { PET, } \\
\text { dosimetry, } \\
\text { therapy }\end{array}$ & $\begin{array}{l}{ }^{64} \mathrm{Cu} \\
12.7 \mathrm{~h}\end{array}$ & ${ }^{64} \mathrm{Cu}$ & $\mathrm{Y}_{2} \mathrm{O}_{3}-\mathrm{VD} 5$ & $1.1 \mathrm{E} 10$ & $2.3 \mathrm{E} 10$ & ${ }^{64} \mathrm{Cu} 5$ & $7.1 \mathrm{E} 9$ & $3.6 \mathrm{E} 8$ & 20 & $2.1 \mathrm{E} 10$ & $3.6 \mathrm{E} 9$ & $\begin{array}{l}\text { Chemical } \\
\text { purification }\end{array}$ \\
\hline PET & $\begin{array}{l}{ }^{61} \mathrm{Cu} \\
3.3 \mathrm{~h} \\
\end{array}$ & ${ }^{61} \mathrm{Cu}$ & $\mathrm{Y}_{2} \mathrm{O}_{3}$-VD5 & 7.7 E9 & 1.7 E10 & ${ }^{61} \mathrm{Cu} 5$ & 5.1 E9 & $2.6 \mathrm{E} 8$ & 20 & 2.1 E10 & $4.0 \mathrm{E} 9$ & $\begin{array}{l}\text { Only mass } \\
\text { separation }\end{array}$ \\
\hline$\beta$ therapy & $\begin{array}{l}{ }^{47} \mathrm{Sc} \\
3.4 \mathrm{~d}\end{array}$ & ${ }^{47} \mathrm{Sc}$ & $\mathrm{Ti}$ & 6.4 E10 & 5.0 E10 & ${ }^{47}$ Sc 5 & 4.2 E10 & $2.1 \mathrm{E} 9$ & 20 & 5.9 E10 & 1.2 E10 & Evaporation \\
\hline PET & $\begin{array}{l}{ }^{44} \mathrm{Sc} \\
4.0 \mathrm{~h}\end{array}$ & ${ }^{44} \mathrm{Sc}$ & $\mathrm{Ti}$ & 4.4 E10 & 6.6 E10 & ${ }^{44} \mathrm{Sc} 6.4$ & 5.7 E10 & $2.9 \mathrm{E} 9$ & 20 & 1.6 E11 & 3.2 E10 & Evaporation \\
\hline PET & $\begin{array}{c}{ }^{11} \mathrm{C} \\
20.3 \mathrm{~m} \\
\end{array}$ & ${ }^{11} \mathrm{CO}$ & $\begin{array}{c}\text { NaF-LiF- } \\
\text { VD5 }^{\diamond} \\
\end{array}$ & - & - & -15 & - & $1.4 \mathrm{E} 9$ & - & - & $4.2 \mathrm{E} 9$ & $\begin{array}{l}\text { Only mass } \\
\text { separation }\end{array}$ \\
\hline
\end{tabular}

SPECT - Single Photon Emission Computed Tomography; PET - Positron Emission Tomography; pps - particle per second. ${ }^{\dagger}$ One-point-four gigaelectron volt proton beam with a $2 \mu$ A intensity and a maximum $5 \times 10^{18}$ total protons delivered to the target; ${ }^{\ddagger}$ a maximum of $5 \times 10^{18}$ proton is delivered to the target; * in-target production of parent isotope; ** RIB stands for radioactive ion beam; $\varepsilon_{\text {extr }}$ is the overall extraction efficiency of the mass separation process; the extraction time varies from two to $10 \mathrm{~h} ;{ }^{\circ}$ applies to a molten salt target unit [2] and not to a CERN-MEDICIS target; isotopes quoted in italics indicate possible collections, while the optimization of the process is required to reach relevant activities for studies with patients; \# the extracted activities at the end of the extraction process ( $2 \mathrm{~h}-10 \mathrm{~h}$ ) will differ from the End-OfBeam (EOB) activities for the most exotic isotopes. 
Table 3. Tentative planning of the construction and staged start-up of the CERN-MEDICIS facility.

\begin{tabular}{lll}
\hline Operation Phase & Milestone & Date \\
\hline Phase I & Commissioning: no beam & end 2015 \\
Phase II & Commissioning with beam and light targets to gain operational experience & 2016 \\
Phase II B & Isotope production with light targets & middle 2016 \\
Phase III & Extending to heavy targets up to tantalum & end 2016 \\
Phase IV & Collection of short-lived alpha emitters (e.g., 149Tb) & 2017 \\
Phase IV B & Operation with lasers & 2018 \\
Phase V & Operation with uranium targets/possible proton beam upgrade & \\
\hline
\end{tabular}

The batches are then checked and shipped to the institutes and hospitals that are part of the CERN-MEDICIS collaboration, on a weekly basis, 30 times per year.

\section{Expected Production Rates}

By placing the CERN-MEDICIS target behind an ISOLDE target, we improved the target design to match the isotope production yields of ISOLDE. However, since the beam is scattered after the primary target, the amount of the secondary target material has to be increased to make up for the loss of protons (Figures 2 and 3), by increasing CERN-MEDICIS's target density and diameter. The optimal volume was defined as $196 \mathrm{~cm}^{3}$, approximately four times ISOLDE's core volume. The densities were also increased.

Figure 2. CERN-MEDICIS sample/target characteristics.

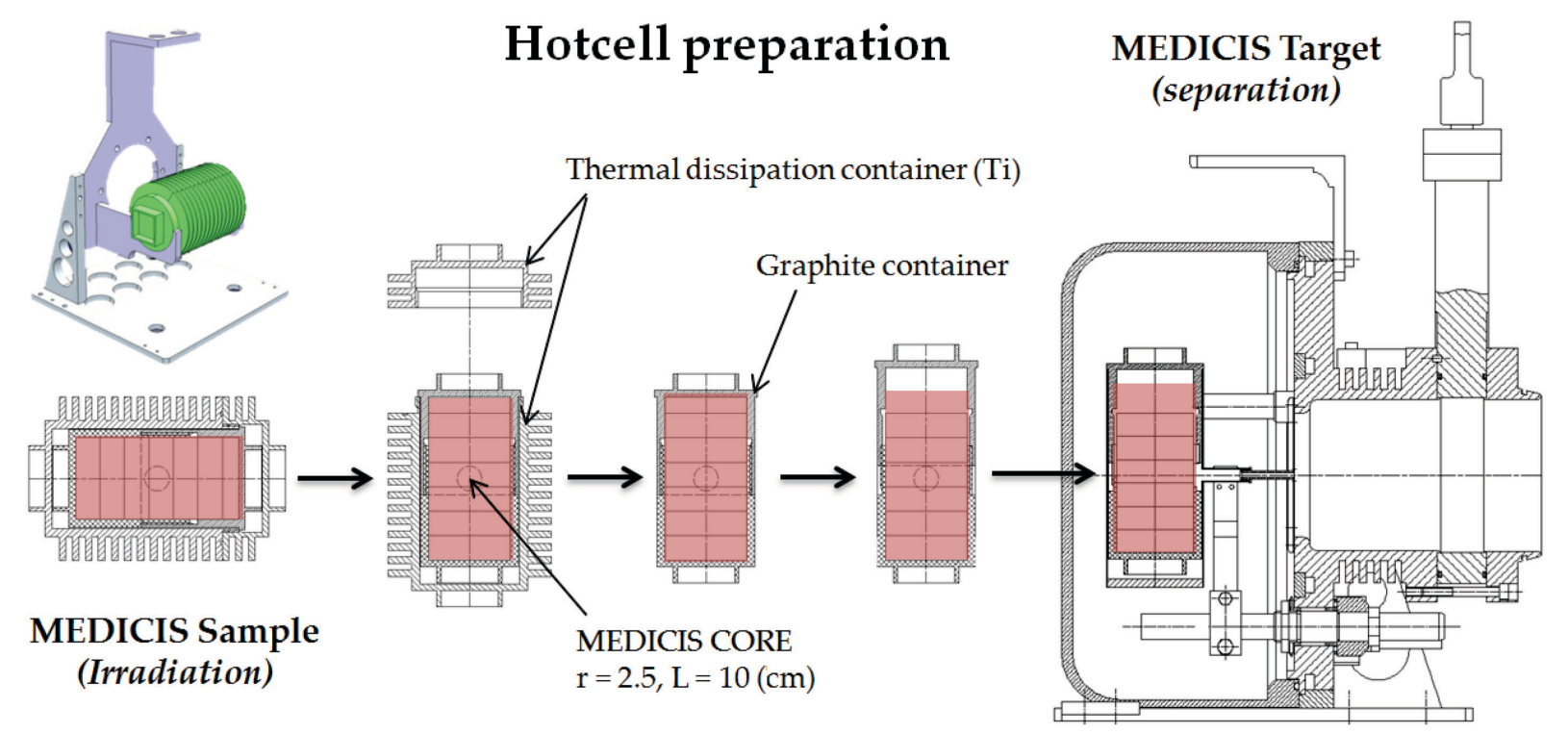

The production rates obtained with CERN-MEDICIS were first studied under ISOLDE and HIE-ISOLDE proton beam characteristics. FLUKA [3,4], a fully integrated particle physics Monte Carlo simulation software package, was used to simulate the in-target yields of the relevant isotopes and combined with experimental extracted yields observed at ISOLDE [5] to obtain the estimates shown in Table 2. Extrapolation is also provided for a possible future upgrade of the proton beam 
characteristics, reaching an average of $6 \mu \mathrm{A}$ and $2 \mathrm{GeV}$ of proton energy. In that case, provided the isotope separation efficiencies are further improved, gigabecquerel production levels for a number of relevant isotopes will become available, with a notable $10 \mathrm{GBq}{ }^{149} \mathrm{~Tb}$ batch production scale, which could take place on a daily basis during the CERN accelerator complex operation.

Our simulated in-target production results are computed for a homogeneous target material. For ISOL (Isotope mass Separation OnLine) isotope extraction, the microstructure of the target is optimized to maximize the extraction efficiency and selectivity during the mass separation process [6]. For this last step, the experience already gained at ISOLDE during the past 40 years is of utmost importance, and possible future developments are expected to provide production gains. The diagram in Figure 3 illustrates the cycle for a CERN-MEDICIS target from its preparation until the isotope extraction, purification and final shipping:

Figure 3. The MEDICIS cycle. * The figure is reprinted with permission from [7].

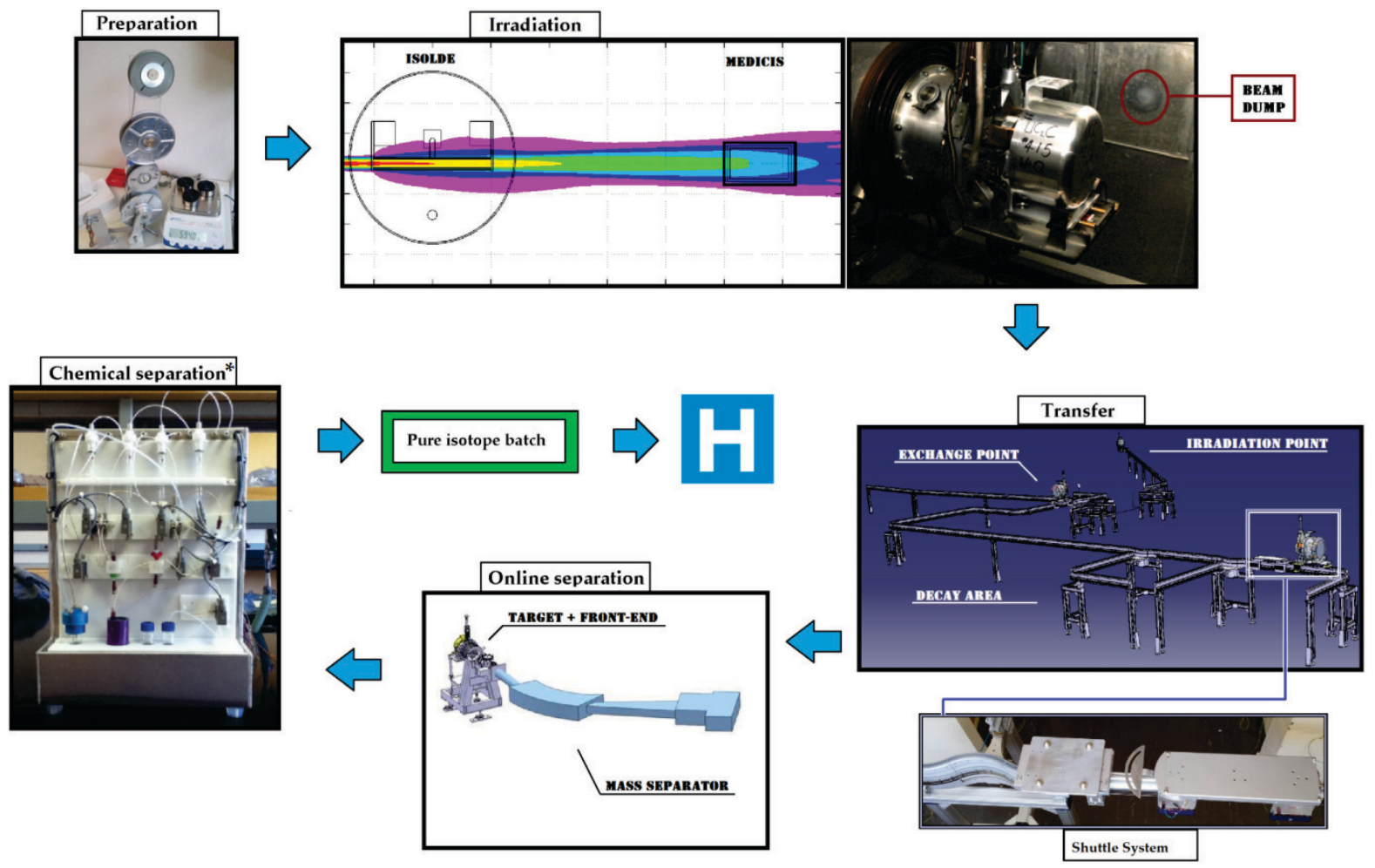

The isotope extraction is preceded by an off-line separation performed in the CERN-MEDICIS bunker, where a dedicated target station equipped with services and an electrostatic acceleration stage will accelerate the nuclei before entering a dipole magnet. There, the radioactive ion beams are deflected in arcs of different radii according to their masses. A selective window is used to filter out the unwanted beams. The isotope mass separator in Figure 4, which will be transferred from the Centre de Ressources du Cyclotron (CRC) Louvain La Neuve/KU Leuven is equipped with a beam switchyard to direct three beams in parallel by means of a set of slits and electrostatic deflectors. The advantage of this feature in the foreseen collection process becomes evident: different isotopes of the same chemical element can be collected, for instance ${ }^{149 / 152 / 155} \mathrm{~Tb}$, providing possible theranostic combinations or extending further to different elements collected from the same target. The isotopes will be implanted in thin metallic foils, in polymeric supports coated with salt layers or directly in ice 
samples. Radioactive isobars, that is isotopes or molecules of different elements extracted at the same mass, which might be obtained in the process of the offline separation, can be further separated from the desired isotope by using, for example, cation exchange chromatography with a given resin and eluent in dedicated glove boxes. In this case, the batches are dissolved in liquid samples to perform the chromatographic separation process. Before shipping, each batch will be finally analyzed by gamma ray spectrometry to determine any possible contamination. The batch shipment procedure will comply with the International Atomic Energy Agency (IAEA) rules for shipping packages containing radioactive material.

Figure 4. Reproduction of the isotope mass separator installed at the CRC at Louvain La Neuve. The beam switchyard shown on the right allows one to perform three batch collections in parallel (courtesy Paul Van den Bergh CRC-KU Leuven).
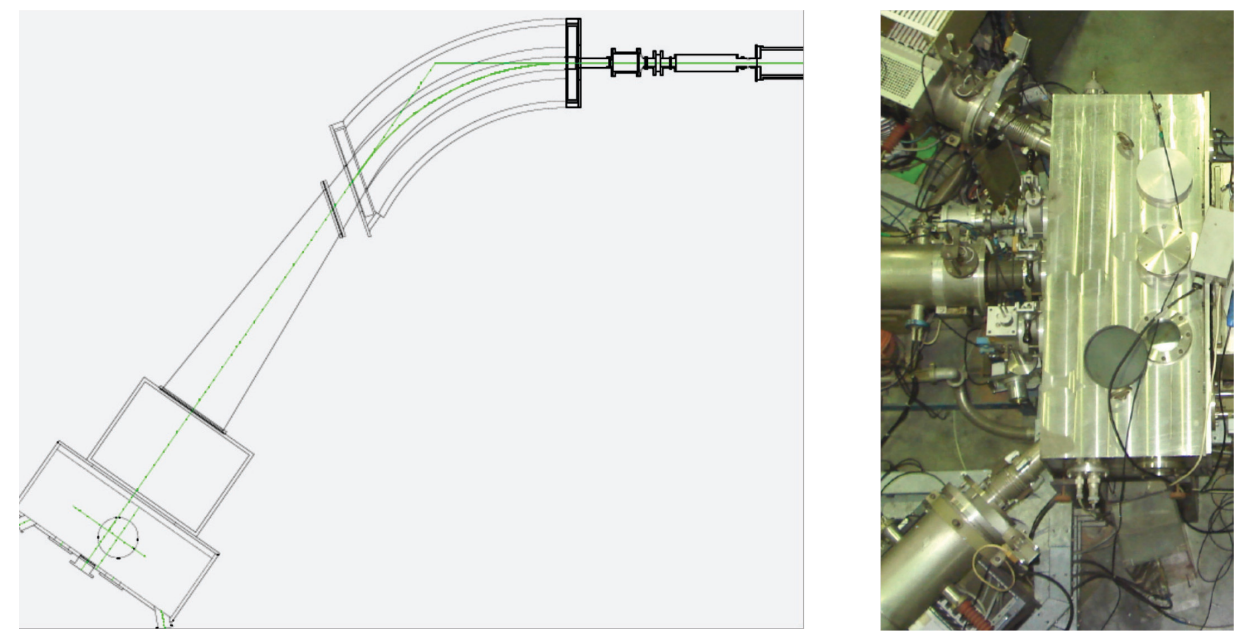

\section{Past and Ongoing Biomedical Activities at ISOLDE/Biomedical Research Performed at ISOLDE}

\subsection{Past Activities}

The first biomedical research ever performed with the use of radionuclides produced at ISOLDE is dated to as early as 1979 , when a batch of around $70 \mathrm{MBq}(2 \mathrm{mCi})$ of ${ }^{167} \mathrm{Tm}$ was produced, transported to Dresden, Germany, labelled with citrate and then injected into a patient suffering from a lymphoma cancer $[8,9]$.

After that, in the early $1980 \mathrm{~s}$, a novel ${ }^{81} \mathrm{Rb}-{ }^{81 \mathrm{~m}} \mathrm{Kr}$ generator for medical use was developed based on the specific behavior of the noble gases implanted into a tape used in the tape transport collection devices existing at that time at ISOLDE and Dubna. In the test experiment performed at ISOLDE in 1983, ${ }^{81} \mathrm{Rb}$ ions were implanted into several host materials, such as Mylar foils, filter paper, polyethylene foil and aluminum foil [10]. The ${ }^{81} \mathrm{Rb}$ implanted foils (4 MBq each) were then mounted at the end of a small gas tube and fixed to a $\mathrm{Ge}(\mathrm{Li})$-detector. For each foil, four different tests were performed: (1) a measurement with no gas in the tube; (2) a measurement with an air stream passing through the tube; (3) a measurement with water as an eluent; and (4) physiological $\mathrm{NaCl}$ as the eluent. The obtained results showed above $85 \%$ release efficiency of ${ }^{81 \mathrm{~m}} \mathrm{Kr}$ from the Mylar foils with different thicknesses and the polyethylene foil, whereas, the efficiency for Al foil did not exceed 5\%. Unexpectedly 
high quantity ${ }^{81 \mathrm{~m}} \mathrm{Kr}$ elution was obtained for both water and $\mathrm{NaCl}$ (above 95\%), thus demonstrating a possible medical application of the ${ }^{81} \mathrm{Rb}_{-}{ }^{81 \mathrm{~m}} \mathrm{Kr}$ generator for use in vivo.

The next biomedical activities based on the isotopes produced at ISOLDE were reported nearly a decade later (1990-1993) when Beyer et al. investigated the influence of EDTMP (ethylenediamine tetra(methylene phosphonic acid) chelator concentration on the bio-distribution of simultaneously injected different radio-lanthanides and ${ }^{225} \mathrm{Ac}$ in mice bearing carcinoma tumor [11-13]. For the purpose of these studies, carrier-free and isotopically clean samples of ${ }^{145} \mathrm{Sm},{ }^{147} \mathrm{Eu},{ }^{149} \mathrm{Gd}$, ${ }^{153} \mathrm{Gd}$ and ${ }^{167} \mathrm{Tm}$ were produced by the interaction of $1 \mathrm{GeV}$ protons with a Ta-foil target and those of ${ }^{141} \mathrm{Ce},{ }^{147} \mathrm{Nd},{ }^{147} \mathrm{Eu}$ and ${ }^{225} \mathrm{Ac}$ from a U-carbide target. The isotopes were implanted into foils and then recovered in the process of radiochemical purification. The highly concentrated $(>50 \mathrm{MBq} / \mathrm{mL})$ samples of a volume of $10 \mu \mathrm{L}$ each containing $0.05 \mathrm{M} \mathrm{HCl}$ were next shipped to the University Hospital in Geneva, where the final solution preparation took place. The cocktail solutions $(0.5 \mathrm{~mL})$ containing different concentrations of EDTMP and about $50 \mathrm{kBq}$ of each isotope were then injected into 30 tumor-bearing mice. The studies of individual bio-distribution of each radio-lanthanide and Ac chelated by EDTMP revealed, on the one hand, much lower liver uptake for all used radio-metals as compared to the citrates and almost no affected tumor uptake, on the other. Consequently, better tumor-to-liver uptake ratios were obtained for all radio-lanthanide and Ac. These ratios, however, turned out to be to a large extent affected by the concentration of the chelating ligand, showing the same close correlation between the ligand concentration and the bio-distribution of metal-chelate complexes in vivo.

Subsequently, two positron emitting isotopes, ${ }^{86} \mathrm{Y}$ (Nb-target) and ${ }^{142} \mathrm{Sm}$ (U-carbide target), were collected in 1993, chelated by EDTMP and, finally, used for quantitative bone imaging in rabbits with a rotating PET (positron emission tomography) scanner at the Department of Radiology, Nuclear Medicine, University of Geneva [14]. The PET studies with ${ }^{86}$ Y-EDTMP constituted the first studies using isotopes produced at CERN that were ever performed in Geneva. The collected activity of ${ }^{86} \mathrm{Y}$ was rather poor, and even though it allowed for obtaining good bone images of rabbits, it was too low for performing any studies on humans. The observed behavior of ${ }^{86}$ Y-EDTMP was as expected: fast blood clearance and non-detectable liver uptake. The PET studies with ${ }^{142} \mathrm{Sm}$-EDTMP were, to the best of our knowledge, the first PET scans ever performed with this isotope. ${ }^{142} \mathrm{Sm}$-EDTMP exhibited, similarly to ${ }^{86}$ Y-EDTMP, a fast blood clearance and undetectable liver uptake. However, the excreted activity was highly accumulated in the bladder [15]. In 1994 the first clinical patient studies with ${ }^{83} \mathrm{Sr}$ and ${ }^{142} \mathrm{Sm}$ were performed and the collaboration between the Department of Medical Biochemistry, University of Geneva, and ISOLDE was fully established [16].

The study of the possible use of radioactive ion beams for biomedical research was then extended to a bio-conjugate (chelator-antibody), which is known to have higher tumor specificity: aminooxyacetyl-ferrioxamine coupled to murine anti carcinoembryonic antigen (CEA) IgG1 monoclonal antibody MAB 35, synthesized by Pochon and co-workers [17]. The chelator-antibody conjugates were labelled by $2 \mathrm{~h}$ incubation in acetate solution with several different lanthanides $\left({ }^{153} \mathrm{Gd}\right.$, ${ }^{169} \mathrm{Yb},{ }^{167} \mathrm{Tm},{ }^{141} \mathrm{Ce}$ ) and ${ }^{225} \mathrm{Ac}$ produced from U-carbide and Ta-foil targets and purified by cation-exchange chromatography column containing $\alpha$-hydroxyisobutyric acid (HIB) [18]. The radiolabelled conjugates were then injected into a sample of nude mice bearing xenografted colorectal tumors at the University Hospital in Geneva. The pharmacokinetic behavior of the radionuclides was 
studied by $\gamma$-ray spectroscopy and further compared to ${ }^{111}$ In-labelled bio-conjugate with a well-known pharmacokinetic behavior. The obtained results showed that radio-lanthanides exhibit an in vivo behavior similar to clinically used ${ }^{111}$ In-labelled immunoconjugates. ${ }^{225}$ Ac-labelled conjugates revealed, however, much faster blood clearance, indicating the same insufficient in vivo stability. This series of experiments was concluded by a comparative study of biokinetics of the octreotide peptide linked to aminobenzyl diethylene triamine pentaacetic acid (DTPA) and labelled with ${ }^{141} \mathrm{Ce},{ }^{143} \mathrm{Pm},{ }^{153} \mathrm{Gd}$ and ${ }^{159} \mathrm{Dy}$ and ${ }^{111} \mathrm{In}$. For the purpose of this study, bio-conjugates were injected into insulinoma bearing rats at the partner hospital. The obtained results showed a similar tissue uptake for all radio-lanthanides and In and slightly better tumor uptake of the lanthanides-labelled forms [19].

The systematic studies described above aimed at the understanding of the biokinetic behavior of radio-lanthanides and radio-lanthanide-labelled bioconjugates in vivo, in order to be able to optimize the conditions for the maximum uptake in the tumor tissue. These studies were followed by experiments aiming at testing several positron emitting lanthanides, which decay to homologue elements that possibly can be used for cancer therapy. Within these studies, it has been shown that, for example, ${ }^{152} \mathrm{~Tb}$ can be used for in vivo dosimetry for monitoring the bio-distribution of ${ }^{149} \mathrm{~Tb}$ in radionuclide therapy [20]. The carrier-free and isotopically clean batches of 500 and $800 \mathrm{MBq}$ of ${ }^{152} \mathrm{~Tb}$ and ${ }^{149} \mathrm{~Tb}$, respectively, were produced at ISOLDE and then transported to the University Hospital in Geneva, where a Jaszcazk phantom was filled with four liters of one activated solution at a time. The comparative PET studies showed significantly better scan quality for ${ }^{152} \mathrm{~Tb}(12 \%$ positron decay) than for ${ }^{149} \mathrm{~Tb}$ (4\% positron decay); however, the energy windows had to be set between 440 and $560 \mathrm{keV}$ in order to reduce the $\gamma$-radiation coming from ${ }^{152} \mathrm{~Tb}$. The recorded PET images were then reconstructed in $3 \mathrm{D}$ mode, revealing significantly better quality for ${ }^{152} \mathrm{~Tb}$ as compared to ${ }^{149} \mathrm{~Tb}$.

The first in vivo experiments demonstrating the efficiency of alpha targeted therapy (TAT) using the only suitable lanthanide produced at ISOLDE, ${ }^{149} \mathrm{~Tb}$, were carried out by Beyer et al. in the summer of 2001 [21-23]. The radio-lanthanide was produced by the irradiation of the Ta-foil target with $1.4 \mathrm{GeV}$ protons, implanted into a thin layer of $\mathrm{KNO}_{3}$ on aluminum backings and separated from isotopic contamination using exchange chromatography column equilibrated with the $\alpha$-HIB eluent. The 5.5 $\mathrm{MBq}{ }^{149} \mathrm{~Tb}$ activity was then used for labelling the rituximab antibody linked to 2-(4-isothiocyanatobenzyl) diethylenetriamine pentaacetic acid (SCN-CHX-A-DTPA). Ready immunoconjugate was injected into a group of around 30 mice two days after xenotransplantation of Daudi cells used to simulate leukemia. The results of the study revealed a full sterilization of the tumor cells and complete protection of the xenografted mice over a period of at least four months. Furthermore, no toxic effects of ${ }^{149} \mathrm{~Tb}$ were observed.

In March, 2002, the first official initiative of running a specific medical isotope program at CERN was presented by Gerd-Jürgen Beyer at the Educational and Technology Transfer (ETT) Seminar at CERN [24]. This initiative was led by Gerd-Jürgen Beyer, Helge Ravn, Ulrich Köster and G. Ragnelly, already started in late 2001 and aiming at creating a radiochemistry laboratory at CERN for the on-site chemical purification of radioisotopes, the development of technologies for different ways of producing medical isotopes based on MegaWatt p-drivers, including off-line mass separation, launching a new international collaboration for bio-medical and nuclear medicine studies and maintaining a constant training of scientific personnel. This initiative lasted for a couple of years and, finally, came to a stand-by status. 


\subsection{Ongoing Research}

Present bio-medical activities at ISOLDE are focused on further tests of the feasibility of the Tb isotopes for tumor imaging and radionuclide therapy, as well as fundamental research in the field of bioinorganic and conjugation chemistry and the relationship between molecule parameters and the biological response or heavy metal toxicity.

In 2012, two independent research groups studied the feasibility of using different $\mathrm{Tb}$ isotopes $\left({ }^{149} \mathrm{~Tb},{ }^{152} \mathrm{~Tb},{ }^{155} \mathrm{~Tb}\right.$ and $\left.{ }^{161} \mathrm{~Tb}\right)$ for imaging and tumor targeted systemic therapy. Franz Buchegger and co-workers examined the in vivo distribution of the ${ }^{152} \mathrm{~Tb}$ labelled 1,4,7,10-tetraazacyclododecane1,4,7,10-tetraacetic acid (DOTA)-RM6 conjugate in severe combined immunodeficiency (SCID) mice bearing the human prostate cancer PC-3. The results of these studies will be published elsewhere. Cristina Müller et al. [25,26] carried out the proof-of-concept study of all four Tb isotopes in order to evaluate their possible diagnostic and therapeutic aspects. For the purpose of these studies ${ }^{149} \mathrm{~Tb},{ }^{152} \mathrm{~Tb}$ and ${ }^{155} \mathrm{~Tb}$ were produced from the Ta-foil target at ISOLDE. The isotopes were implanted into a zinc-coated foil. ${ }^{161} \mathrm{~Tb}$ was produced either by $2-3$ weeks of irradiation of the highly enriched ${ }^{160} \mathrm{Gd}$ targets with neutrons at the spallation neutron source (SINQ) at the Paul Scherrer Institute (PSI) in Villigen, Switzerland, or by one week of irradiation at the high-flux nuclear reactor at the Institut Laue-Langevin (ILL) in Grenoble, France. All isotopes were then purified by cation-exchange chromatography column and linked to the DOTA-folate conjugate, cm09, and injected into KB-tumor bearing nude mice. The results obtained during these studies confirm excellent tumor visualization in PET $\left({ }^{152} \mathrm{~Tb}\right)$ and SPECT $\left({ }^{155} \mathrm{~Tb}\right)$, as well as the good therapeutic effectiveness of ${ }^{149} \mathrm{~Tb}$ and ${ }^{161} \mathrm{~Tb}$ for $\alpha$ and $\beta$-therapy, respectively.

The first biophysics activities at ISOLDE are dated to more than 20 years ago, when in November, 1990, Tilman Butz and Wolfgang Tröger performed preliminary experiments with ${ }^{199 \mathrm{~m}} \mathrm{Hg}$ bound to ascorbate oxidase and laccase using the perturbed angular correlation of $\gamma$-rays (PAC) spectroscopy technique [27]. ${ }^{199 \mathrm{~m}} \mathrm{Hg}$ was collected into ice hosted by a small $\mathrm{Cu}$ sample-holder and kept at approximately $100 \mathrm{~K}$ in order to guarantee the vacuum in the beam line. After the implantation, the activated ice was thawed slowly in the fume hood located in the off-line laboratory and added to a solution containing the proteins. The obtained results demonstrated unambiguously that PAC spectroscopy can be applied to study biological samples [28,29]. These studies were then followed by several successful experimental campaigns, and the research was extended to other isotopes, such as ${ }^{111 \mathrm{~m}} \mathrm{Cd}$ [30-33]. In early 2006, the project was taken over by the biophysics and bioinorganic chemistry groups from the University of Copenhagen, Denmark, led by Lars Hemmingsen. The major focus of the research was continuously kept on investigating the metal ion behavior at the molecular level and under physiological conditions and on the heavy-metal ion toxicity of $\mathrm{Hg}$ (II), $\mathrm{Pb}$ (II) and $\mathrm{Cd}$ (II) metal ions [34-36]. In addition, the year 2012 was particularly successful for the biophysics collaboration, because a new apparatus allowing for $\beta$-NMR experiments on liquid samples was finally established at ISOLDE and tried in the world's first experiments in an ionic liquid. The results of this study will soon be published elsewhere [37]. 


\section{Perspectives}

\subsection{Newly Established International Collaboration}

The CERN-MEDICIS facility has triggered the interest of neighboring medical institutions and beyond. Several of those are already part of the collaboration, such as the local university hospitals of Geneva and Lausanne and the Swiss Experimental Cancer Research Institute (ISREC), at École Polytechnique Fédérale de Lausanne (EPFL). The techniques used to produce the isotope batches, combining mass separation and radiochemical purification techniques, are supported by nuclear physics and radiochemistry groups in Leuven in Belgium and Kolkata in India.

\subsection{New Radioisotopes}

As listed in Table 2, a wide range of radioisotopes covering positron emitters, Auger and conversion electron emitters and alpha emitters will be available from CERN-MEDICIS. In addition, various chemical species, such as lanthanides, halogens, transition metals and alkaline earth metals, will be produced and will cover a wide range of chemical approaches to synthesize bioconjugates with proper targeting capabilities.

\subsection{New Bioconjugates and Chelators}

New bioconjugates targeted towards prostate and pancreatic cancers will be investigated. For many cancer types, malignant cells present an overexpression of regulatory peptide receptors. Peptides specific to these receptors, linked to isotopes, have been used to localize tumors in vivo by scintigraphy or PET-imaging. Clinical trials have also tested such peptides to treat cancer (a method called peptide receptor radiotherapy or PRRT). The molecules used for PRRT are made up of three parts: the peptide specific for the receptor, the chelator capable of binding the isotopes and the isotopes. iRGD is a tumor-homing peptide that acts via a three-step process: the RGD motif mediates binding to the alpha $\mathrm{v}$ integrins on tumor endothelium and then exposes a binding motif for neuropilin-1, which mediates penetration into tissue and cells. Conjugation to iRGD significantly improved the sensitivity of tumor-imaging agents and enhanced the activity of anti-tumor drugs. New bioconjugates incorporating these peptides have notably been studied at ISREC-EPFL, a partner of CERN-MEDICIS.

\subsection{New Approaches in Brachytherapy}

At the Hôpitaux Universitaires de Genève (HUG), Da Vinci systems are available for minimally invasive robotic-assisted surgery. These robotic systems can be coupled with endoscopic ultrasonography to deliver seeds in non-respectable pancreatic tumors or metastases. Extending to neurosurgery, stereotactic surgery coupled with computerized tomography is by now routinely used. New combinations will use stereotactic surgery coupled with magnetic resonance imaging, capabilities that will be available at HUG. These delivery methods will be tested for future clinical applications of brachytherapy. This will be done testing different types of radioactive seeds and, more particularly, focusing on the use of alpha-emitters. 


\section{Conclusions}

The construction of the CERN-MEDICIS facility has started with its ground-breaking ceremony in September, 2013. The equipment and services will progressively be integrated in the building, while the ISOLDE facility resumes operations in the summer of 2014. The new facility is expected to be commissioned towards the end of 2015. Along with the development of the infrastructures, the collaboration with the medical and life science community is active and expanding. Besides the test collections and shipping done in 2012 with the Service de Medicine Nucleaire at Centre Hospitalier Universitaire Vaudois (CHUV), novel approaches in brachytherapy have been elaborated with Geneva Hospital (HUG). Possible upgrades of the proton beam delivered to CERN-MEDICIS and ISOLDE notably opens the way to $10 \mathrm{GBq}$-scale production of ${ }^{149} \mathrm{~Tb}$ on a daily basis. Investigations of Auger emitters with the Radiopharmacy group in Centro de Ciências e Tecnologias Nucleares (C2TN)-Lisbon have now been incorporated in the research plans. The perspective of a dedicated facility at CERN for the production of innovative isotopes, together with local leading institutes in life and medical sciences and with a large network of laboratories gives exciting prospects for this scientific program in the coming years.

\section{Acknowledgments}

The CERN-MEDICIS project and collaboration is rapidly expanding, starting from the first exchanges of ideas that took place three years ago around a cup of coffee. New publications are expected to reflect about the various contributions of the different members of the project and about the milestones when they are met in the near future.

\section{Conflicts of Interest}

The authors declare no conflict of interest.

\section{References}

1. Stora, T.; Da Visitacao, S.F.; Mathot, S.; Bowen, P. Nanostructured Target for Isotope Production. U.S. Patent 20110235766 A1, 29 September 2009.

2. Mendonca, T.M.; Hodak, R.; Ghetta, V.; Allibert, M.; Heuer, D.; Noah, E.; Cimmino, S.; Delonca, M.; Gottberg, A.; Kronberger, M.; et al. Production and release of ISOL beams from molten fluoride salt targets. Nucl. Instrum. Methods Phys. Res. Sect. B 2014, submitted for publication.

3. Battistoni, G.; Muraro, S.; Sala, P.R.; Cerutti, F.; Ferrari, A.; Roesler, S.; Fassò, A.; Ranft, J. The FLUKA code: Description and benchmarking. In Proceedings of the Hadronic Shower Simulation Workshop AIP Conference, Fermilab, Batavia, IL, USA, 6-8 September 2006; Albrow, M., Raja, R., Eds., American Institute of Physics: Melville, New York, NY, USA, 2007; Volume 896, pp. 31-49.

4. Ferrari, A.; Sala, P.R.; Fassò, A.; Ranft, J. FLUKA: A Multi-Particle Transport Code; CERN-2005-10; CERN: Geneva, Switzerland, 2005.

5. Access to the Yield information. Available online: https://oraweb.cern.ch/pls/isolde/query_tgt (accessed on 24 September 2013). 
6. Stora, T.; Noah, E.; Hodak, R.; Hirsh, T.Y.; Hass, M.; Kumar, V.; Singh, K. Sergey Vaintraub, Pierre Delahaye, Hanna Franberg-Delahaye, Marie-Genevieve Saint-Laurent and Gerard Lhersonneau. A high intensity $6 \mathrm{He}$ beam for the $\beta$-beam neutrino oscillation facility. $E P L \mathbf{2 0 1 2}$, 98, 32001.

7. Morley, T.J.; Dodd, M.; Gagnon, K.; Hanemaayer, V.; Wilson, J.; McQuarrie, S.A.; English, W.; Ruth, T.J.; Benard, F.; Schaffer, P. An automated module for the separation and purification of cyclotron-produced ${ }^{99 \mathrm{~m}} \mathrm{TcO}_{4}$. Nuclear Med. Biol. 2012, 39, 551-559.

8. Beyer, G.J. Radioactive ion beams for biomedical research and nuclear medical application. Hyperfine Interact. 2000, 129, 529-553.

9. Beyer, G.J.; Münze, R.; Fromm, W.D.; Franke, W.G.; Henke, H.; Khalkin, V.A.; Lebedev, N.A. Spallation-produced thulium-167 for medical applications. Med. Radionucl. Imaging IAEA 1980, 1, 587-598.

10. Beyer, G.J.; Ravn, H.L.; Huang, Y.; ISOLDE collaboration. A new type of ${ }^{81} \mathrm{Rb}^{-}{ }^{81 \mathrm{~m}} \mathrm{Kr}$ generator for medical use. J. Appl. Radiat. Isot. 1984, 35, 1075-1076.

11. Beyer, G.J.; Bergmann, R. Workshop on Endoradionuclide Therapy, Dresden, Germany, 30 October-2 November 1990.

12. Beyer, G.J.; Offord, R.; Künzi, G.; Aleksandrova, Y.; Ravn, U.; Jahn, S.; Backe, J.; Tenblad, O.; Lindroos, M.; ISOLDE Collaboration. The influence of EDTMP-concentration on the biodistribution of radio-lanthanides and 225-Ac in tumor-bearing mice. Nucl. Med. Biol. 1997, 24, 367-372.

13. Proposal to the ISOLDE committee, CERN/ISC-4/P42 (ISOLDE experiment ISC330). Available online: https://cds.cern.ch/record/5299? ln=en (accessed on 14 April 2014).

14. Proposal to the ISOLDE committee, CERN/ISC93-14/ISC/P48 (ISOLDE experiment ISC331). Available online: https://cds.cern.ch/record/5298?ln=en (accessed on 14 April 2014).

15. Addendum to the proposal to the ISOLDE committee, CERN/ISC93-14/ISC/P48. Available online: http://cds.cern.ch/record/297279/ (accessed on 14 April 2014)

16. Addendum 1 to ISOLDE experiments ISC330 and ISC331 from 4 May 1994. Available online: https://cds.cern.ch/record/294853/files/SC00000194.pdf (accessed on 14 April 2014).

17. Pochon, S.; Buchegger, F.; Pélegrin, A.; Mach, J.P.; Offord, R.E.; Ryser, J.E.; Rose, K. A novel derivative of the chelon desferrioxamine for site specific conjugation to antibodies. Int. J. Cancer 1989, 43, 1188-1194.

18. Beyer, G.J.; Offord, R.E.; Künzi, G.; Jones, R.M.L.; Ravn, U.; Alexandrova, Y.; Werlen, R.C.; Mäcke, H.; Lindroos, M.; Jahn, S.; et al. Biokinetics of monoclonal antibodies labeled with radio-lanthanides and 225-Ac in xenografted nude mice: Preliminary results. J. Lab. Comp. Radiopharm. 1995, 37, 529-530.

19. Beyer, G.J.; Offord, R.E.; Warlen, R.; Künzi, G.; Alexandrova, Y.; Mäcke, H.; ISOLDE collaboration. Comparison of the biokinetics of octreotide labeled with radio-lanthanides and ${ }^{111} \mathrm{In}$ in tumor bearing rats. Eur. J. Nucl. Med. 1996, 23, 1029-1132.

20. Beyer, G.J.; Morel, C.; Slosman, D.; Sakar, S.; Allen, B.J.; ISOLDE collaboration. Is Tb-152 suitable to monitor tissue doses in alpha therapy with Tb-149 using PET? Eur. J. Nucl. Med. 1998, 25, 837-1196. 
21. Beyer, G.J.; Miederer, M.; Vranješ-Durić, S.; Čomor, J.J.; Künzi, G.; Hartley, O.; Senekowitsch-Schmidtke, R.; Soloviev, D.; Buchegger F.; ISOLDE collaboration. Targeted alpha therapy in vivo: Direct evidence for single cancer cell kill using ${ }^{149}$ Tb-rituximab. Eur. J. Nucl. Med. Mol. Imaging 2004, 31, 547.

22. Proposal to the ISOLDE committe CERN/97-14/ISC/P-90 (ISOLDE experiment IS363). Available online: https://cds.cern.ch/record/491305? $1 n=e n$ (accessed on 14 April 2014).

23. Addendum 1 to IS363 dated 31 January 2000. Available online: https://cds.cern.ch/record/430342?ln=en (accessed on 14 April 2014).

24. Beyer, G.J. Medical application of Radioactive ion beams. Presented at NuPEC, CERN, Geneva Switzerland, 10-12 October 2005.

25. Müller, C.; Zhernosekov, K.; Köster, U.; Johnston, K.; Dorrer, H.; Hohn, A.; van der Walt, N.T.; Türler, A.; Schibli, R. A unique matched quadruplet of terbium radioisotopes for PET and SPECT and for $\alpha$ - and $\beta$-Radionuclide Therapy: An in vivo proof-of-concept study with a new receptor-targeted folate derivative. J. Nucl. Med. 2012, 53, 1951-1959.

26. Buchegger, F.; Tourwe, D.; Kosinski, M.; Viertl, D.; Stora, T.; Buehler, L.; Miralbell, R.; Prior, J. ${ }^{68}$ Ga-labeled NODAGA- and DOTA-neurotensin analogs for targeting breast, prostate and pancreas cancers. Available online: http://www.radiologiekongress.ch/cms/website.php?id=/de/ attendees/program.htm (accessed on 14 April 2014).

27. Butz, T.; Saibene, S.; Fraenzke, T.; Weber, M. A TDPAC-camera. Nucl. Instrum. Methods Phys. Res. Sect. A 1989, 284, 417-421.

28. Proposal to the ISOLDE committee CERN/ISC91-92/ISC/P20. Available online: https://cds.cern.ch/record/5746? ln=en (accessed on 14 April 2014).

29. Butz, T.; Tröger, W.; Messerchmidt, A.; Thoenes, U.; Huber, R. ${ }^{199 \mathrm{~m}} \mathrm{Hg}$-derivatives of ascorbate oxidase and laccase: Selective depletion and blocking of Cu-sites. Hyperfine Interact 1993, 80, 1127-1132.

30. Tröger, W.; Lippert, C.; Schmidt, P.; Schmidt, U.; Butz, T.; Hoffman, R.; Zeppezauer, M.; ISOLDE collaboration. Hg-coordination studies of cysteine containing oligopeptides. Z. Naturforsch. A 1996, 51, 427-430.

31. Tröger, W.; Lippert, C.; Butz, T.; Sigfriddsson, K.; Hannson, Ö.; Mclaughhlin, E.; Bauer, R.; Danielsen, E.; Hemmingsen, L.; Bjerrum, M.J.; ISOLDE collaboration. Small scale intramolecular flexibility in ${ }^{111 \mathrm{~m}} \mathrm{Cd}$-plastocyanin. Z. Naturforsch. A 1996, 51, 431-436.

32. Ctortecka, B.; Tröger, W.; Mallion, S.; Butz, T.; Hoffmann, R. Hg-coordination studies of oligopeptides containing cysteine, histidine and tyrosine by ${ }^{199 \mathrm{~m}} \mathrm{Hg}$-TDPAC. Hyperfine Interact. 1999, 120-12, 737-743.

33. Soldner, T.; Tröger, W.; Butz, T.; Blaha, P.; Schwarz, K.; ISOLDE collaboration. Measurement and calculation of electric field gradients in Hg-mercaptides. Z. Naturforsch. A 1998, 53, 404-410.

34. Iranzo, O.; Thulstrup, P.W.; Ryu, S-b.; Hemmingsen, L.; Pecoraro, V.L. The application of ${ }^{199} \mathrm{Hg}$ NMR and ${ }^{199 m}$ Perturbed Angular Correlation (PAC) Spectroscopy to define the biological chemistry of $\mathrm{Hg}(\mathrm{II})$ : A case study with designed two- and three-stranded coiled coils. Eur. J. Chem. 2007, 13, 9178-9190. 
35. Chakraborty, S.; Kravitz, J.Y.; Thulstrup, P.W.; Hemmingsen, L.; de Grado, W.F.; Pecoraro, V.L. Design of a three-helix bundle capable of binding heavy metals in a triscysteine environment. Angew. Chem. 2011, 50, 2049-2053.

36. Luczkowski, M.; Zeider, B.A.; Hinz, A.V.H.; Stachura, M.; Chakraborty, S.; Hemmingsen, L.; Huffman, D.L.; Pecoraro, V.L. Probing the coordination environment of the human copper chaperone HAH1: Characterization of $\mathrm{Hg}(\mathrm{II})$-bridged homodimeric species in solution. Eur. J. Chem. 2013, 19, 9042-9049.

37. Gottberg, A.; Stachura, M.; Kowalska, M.; Bissell, M.L.; Arcisauskaite, V.; Blaum, K.; Helmke, A.; Johnston, K.; Kreim, K.; Larsen, F.H.; et al. Billion-fold sensitivity improvement in NMR spectroscopy of magnesium ions in solution. Angew. Chem. Unpublished work, 2014.

(C) 2014 by the authors; licensee MDPI, Basel, Switzerland. This article is an open access article distributed under the terms and conditions of the Creative Commons Attribution license (http://creativecommons.org/licenses/by/3.0/). 